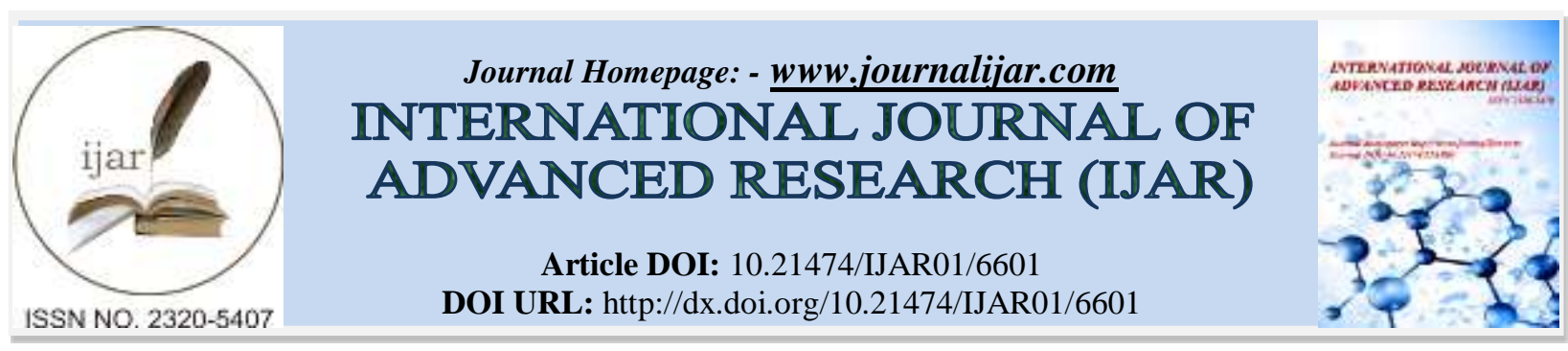

RESEARCH ARTICLE

\title{
DIVERSITY AND USE OF ARTISANAL POTASH FROM AGRICULTURAL CO-PRODUCTS IN CÔTE D'IVOIRE.
}

\section{"Kan Benjamin Kouamé ${ }^{1}$, Massé Diomandé ${ }^{1}$, Anauma Casimir Koko ${ }^{1}$, Ibrahim Konaté ${ }^{1}$ and Nogbou Emmanuel Assidjo².}

1. Laboratoire d'Agrovalorisation, Unité de Formation et de Recherches Agroforesterie, Université Jean Lorougnon Guédé, BP 150 Daloa (Côte d'Ivoire).

2. Laboratoire de Procédés Industriels Synthèse et de l'Energie Nouvelle (LAPISEN), Département de Génie Chimique et Agroalimentaire, Institut National Polytechnique Houphouët-Boigny, BP 1093 Yamoussoukro (Côte d'Ivoire).

\section{Manuscript Info}

Manuscript History

Received: 21 December 2017

Final Accepted: 23 January 2018

Published: February 2018

Key words:-

home-made potash, hygroscopic products, agricultural waste, valorization.

\section{Abstract}

Agriculture occupies most of the Ivorian economy. Thus, huge quantities of agricultural co-products are released into the wild as waste. It is therefore important to value agricultural co-products. This study aims to contribute to the valorization of agricultural co-products through the production of potash. For this purpose, a survey was conducted in the Haut Sassandra region. The questionnaire focused on the identification of co-products used, production processes, the use of artisanal potash and conservation equipment. In addition, a physicochemical analysis of the most produced and available potash on the market was carried out in the laboratory. The results revealed that various co-products are used to produce potash, and that cocoa pods, banana stalks, palm branches and coffee parches are the most commonly used. As for the production method, it is identical according to whether it is done with a co-product or another, with some differences in the production of artisanal potash from the palm branches. At the level of its use, potash is used as a food additive but also as a traditional medicine and in the production of soaps. It is preserved in plastic packaging $(62.91 \%)$, in rubber boxes $(22.77 \%)$, in empty bottles (13.23\%) and in polypropylene bags $(1.08 \%)$.

Copy Right, IJAR, 2018,. All rights reserved.

\section{Introduction:-}

Economy of Côte d'Ivoire is based mainly on agriculture, which is made up of traditional export crops, including cocoa and coffee. Today it extends to other export crops such as oil palm, rubber, pineapple, sugar cane, cotton, banana, etc., and food crops such as plantain, yam, cassava (BAFD/OCDE, 2006). The agricultural sector was the main engine of Ivorian growth after independence with the development of cash crops and food crops promoted by the State. It contributes $22.3 \%$ of PIB (BM, 2013) and accounts for $47 \%$ of the country's total exports in 2013 (62\% excluding oil). It occupies $46 \%$ of the country's labor force and is a source of income for two-thirds of a population at 50.3\% rural (Anonymous 1, 2014). Côte d'Ivoire is the world's largest cocoa producer and second largest producer of cashew nuts, with natural agricultural potential (fertile land, significant hydrological resources, favorable climate) 
and a variety of agro-ecological conditions (Sangare et al., 2009). This agriculture employs about $67 \%$ of the working population in Côte d'Ivoire (Anonymous 2, 2013).

Despite this, it is clear that agricultural co-products (by-products) derived from cash crops (cocoa pod, coffee film, cashew apple, mango waste) and food crops (banana stub and peel, yam, rice sounds, pineapple residues, corn cobs) are found in abundance in production areas. The large tonnages of agricultural products such as pineapple (133 676 tonnes), plantain (1 145000 tonnes), cocoa (1 315000 tonnes), coconuts (253 394000 tonnes) (Freiwalds, 1974, Mara, 1992 et Grigoraş, 2012). Some authors estimate between $10 \%$ and $50 \%$ of co-products obtained from cash crops in West Africa (Freiwalds, 1974). Exploitation of agricultural co-products with a view to recovery has, over the last few years, gained renewed interest for economic as well as environmental reasons (Boucherba, 2015). However, today, the observation is that a multitude of these agricultural co-products are still considered waste so unnecessary and discharge into the environment with its lot of pollution.

Thus, the transformation of these agricultural co-products into artisanal potash could constitute not only a lucrative activity, but a way of solving the improvement of the environment. In Côte d'Ivoire, the valuation of agricultural coproducts in potash requires the existence of an updated database on their knowledge, production, conservation, distribution, use and socio-cultural considerations. Moreover, the choice of the valorization of agricultural coproducts made of artisanal potash for use in the food and medicinal field resides in the fact that there has been little work done in Côte d'Ivoire. Indeed, the production of artisanal potash requires a relatively long time and many unitary operations more or less tedious. It should, therefore, be observed that the shelf-life of artisanal potash is limited in time, like all foodstuffs; as this product is hygroscopic. There is therefore a problem of conservation of this foodstuff with regard to all its virtues. For this reason, the present study, which focuses on the valuation of agricultural co-products made of artisanal potash, makes sense. The present work therefore proposes to describe all the flows during the production activity. The main objective is to contribute to the valorization of agricultural coproducts through the study of the production of artisanal potash in Haut Sassandra (Côte d'Ivoire). More specifically, it concerns:

- to make an inventory of the various agricultural co-products used and to understand the various methods of manufacturing artisanal potash among the rural population;

- assess the use of potash in rural areas and determine the different packaging used for its conservation.

\section{Material and methods:-}

\section{Study site:-}

The study was conducted in the localities of Daloa, Issia and Vavoua in the Haut Sassandra region in the west central Côte d'Ivoire (Fig. 1). The geographical position is given by the following coordinates $6^{\circ} 53$ 'North $6^{\circ}$ $27^{\prime}$ Ouest. It is located in a forest area with temperatures from $21-31^{\circ} \mathrm{C}$. It is located $141 \mathrm{~km}$ from the political capital Yamoussoukro and $383 \mathrm{~km}$ from Abidjan the economic capital. The climate of the region has four seasons: the long rains (April to mid-July), the short dry season (mid-July to mid-September), a small rainy season (midSeptember to November) and large dry season (December to March).

\section{Socio-agricultural and economic survey:-}

A population survey was conducted to identify producers, traders and consumers of artisanal potash in the Haut Sassandra region of Côte d'Ivoire. The aim was to identify the various co-products used for the production of artisanal potash and to understand the various production processes and methods. It was also a question of knowing the use made of the latter and the material used in the conservation of this product. This study was carried out in the localities of Daloa, Vavoua and Issia, in town as well as in the village, in markets and households with indigenous, allochthonous and alien populations. Six hundred and sixty-one (661) of them, located in the towns of Daloa, Vavoua and Issia, as well as in the surrounding villages, were selected at random as part of our investigation. Within each locality, the respondents were selected on the basis of their knowledge of artisanal potash. They are producers of 150 people, traders (179 people) and consumers (332 people).

\section{Statistical Analysis:-}

After the data collection phase in the field, the next step was to analyze and analyze the data collected and process them according to a methodology that would enable us to achieve the various objectives of the study. The survey 
sheets were analyzed using the statistical software EPIDATA 3.0 and the data was transmitted on Microsoft Excel 2016. It enabled us to create a database with the different information collected. The data collected from the respondents were expressed in percentages and then presented in graphs and tables.

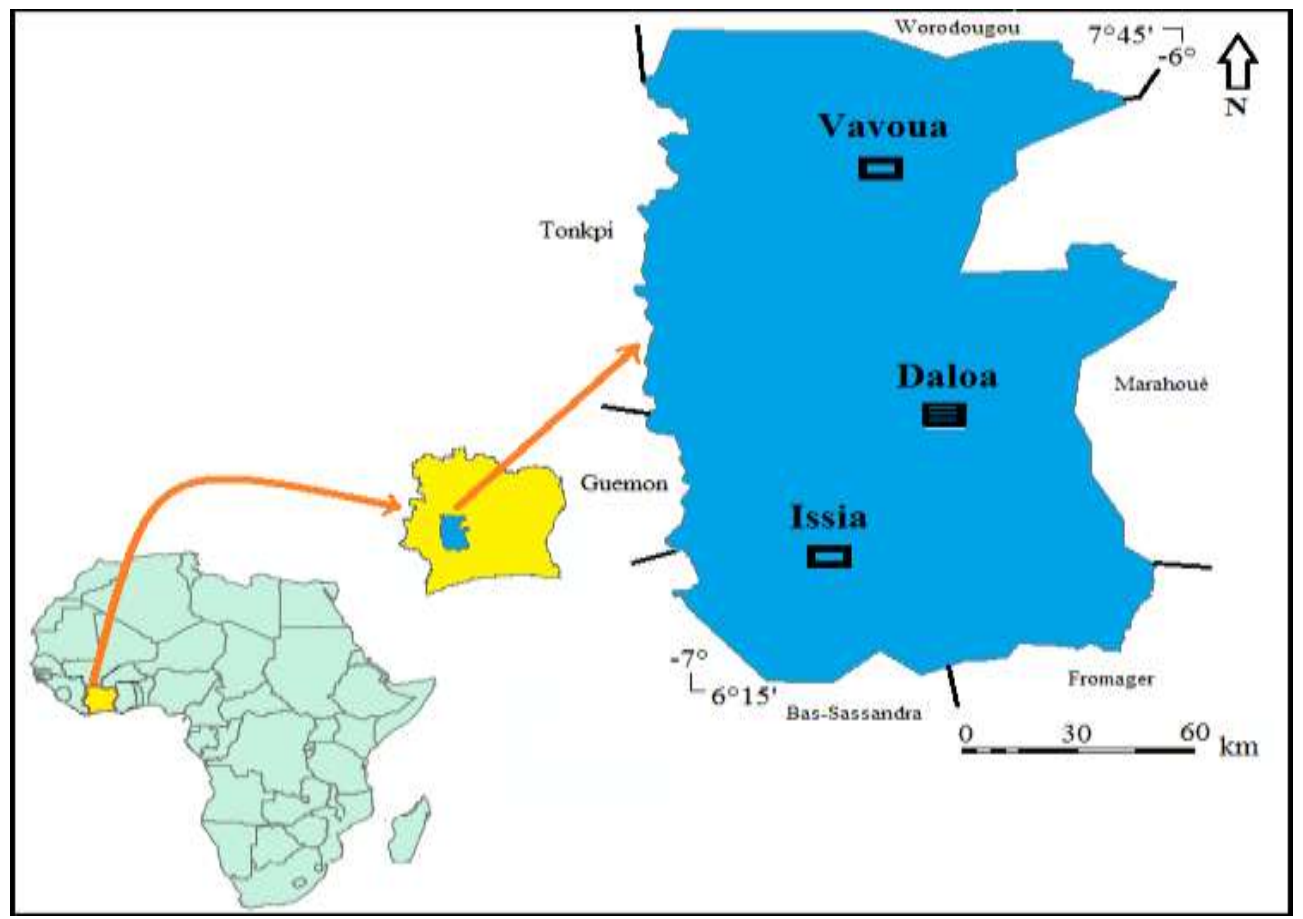

Figure 1:- Location of study area

\section{Results:-}

\section{Inventory of co-products used for the production of artisanal potash:-}

\section{- Socio-demographic characteristics of the respondents}

The surveyed population is estimated at 661 people, of whom $17.14 \%$ are men and $82.86 \%$ are women (Fig. 2). Of these, only $6.94 \%$ are producers and $23.64 \%$ traders of potash. The largest number of respondents $(69.41 \%)$ are consumers (Fig. 3). In addition, the production and marketing activity is carried out exclusively by women. The age of the respondents varies from 20 to 50 years and over, with a majority between 30 and 40 years old. The majority of respondents are non-native (50.76\%) followed by indigenous (30.15\%) and non-native (19.09\%) (Fig. 4). It would use potash both for their consumption as for the traditional treatment of certain diseases and the manufacture of handmade soap.

\section{- Identification of agricultural co-products used for the production of artisanal potash}

Hand-made potash called "Blô" in Akan, "sêguê" in Malinke, "Gbongue" in the Sénoufo language and "Gô" in the Bete language, is produced with a multitude of agricultural co-products including cocoa pods, banana stubbles, coffee beans, banana peels, palm branches, cheesewood, yam peels, corn cobs, residues from the palm seed diet, ash from wood fires, coir and coconut shell and coconut branches and branches of raffia. However, the most commonly used for this production are co-products of cocoa pods, coffee parchments, palm branches and banana stubble. Artisanal potashes derived from these have been the subject of physicochemical analyzes in the rest of this work. The other co-products are used rarely in households to produce potash for personal consumption when time permits them according to the respondents. 
Identification of basic material preferences in potash production and description of artisanal production methods:-

\section{- Identification of basic material preferences in the production of artisanal potash in} producers

During the investigation, four main co-products used for the production of artisanal potash were identified. In our sample, the majority of potash producers use co-products from cocoa (cocoa pods), coffee (coffee hulls) and banana (banana stubble), while only a minority use those from the palm tree (branches of the palm tree) (Fig. 5).

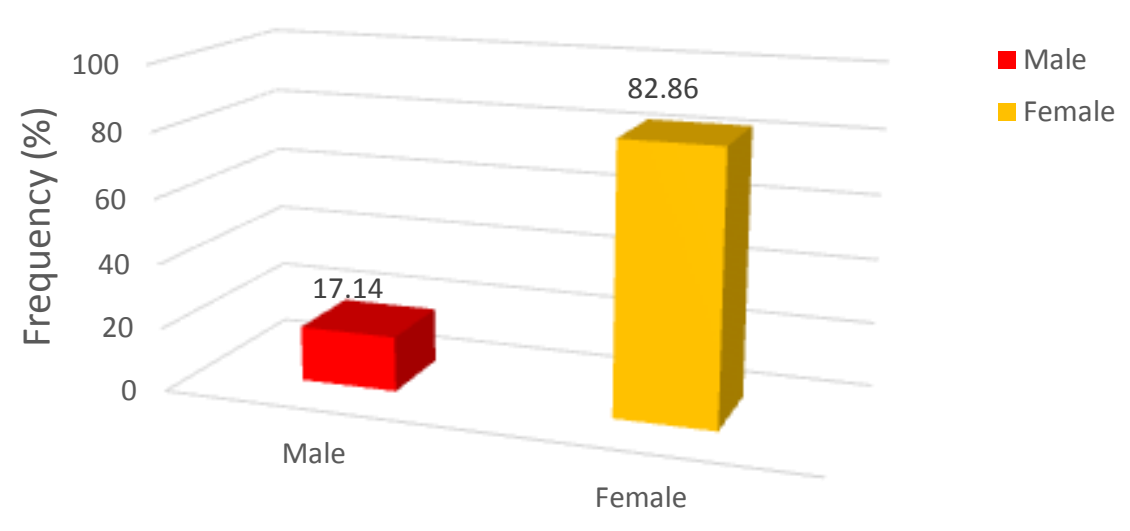

Sexes surveyed

Figure 2:- Frequency of respondents by sex

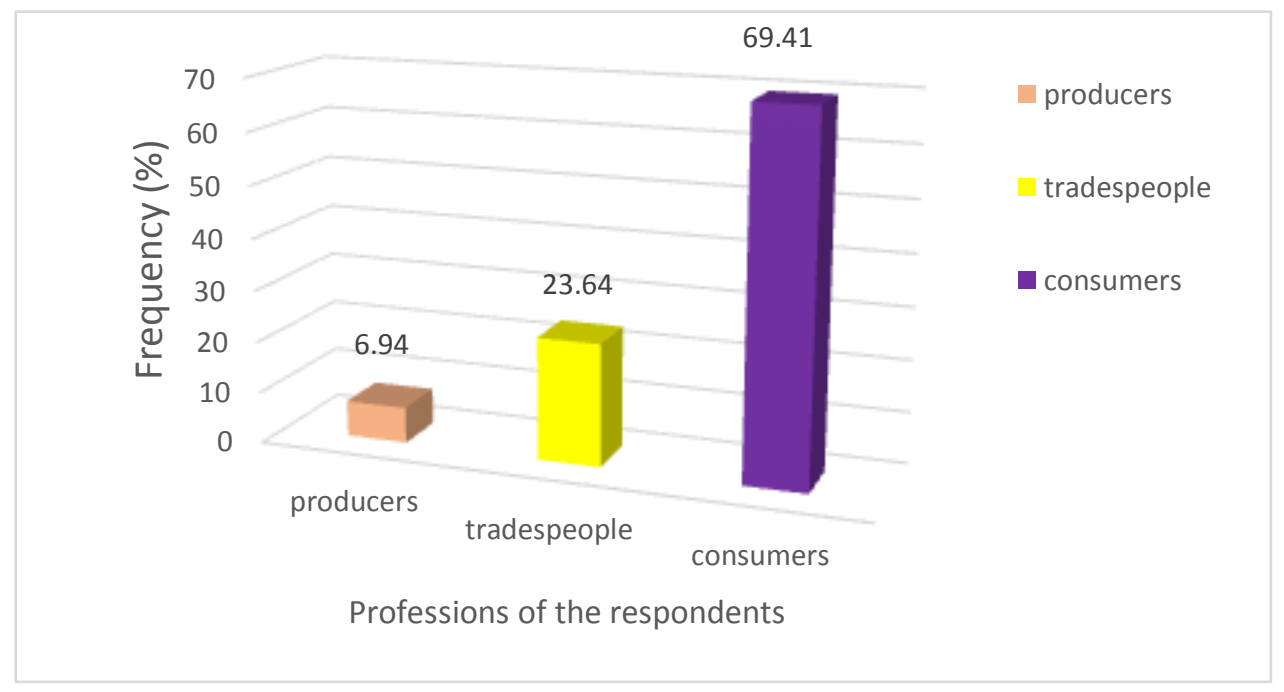

Figure 3:- Frequency of the occupations of the respondents

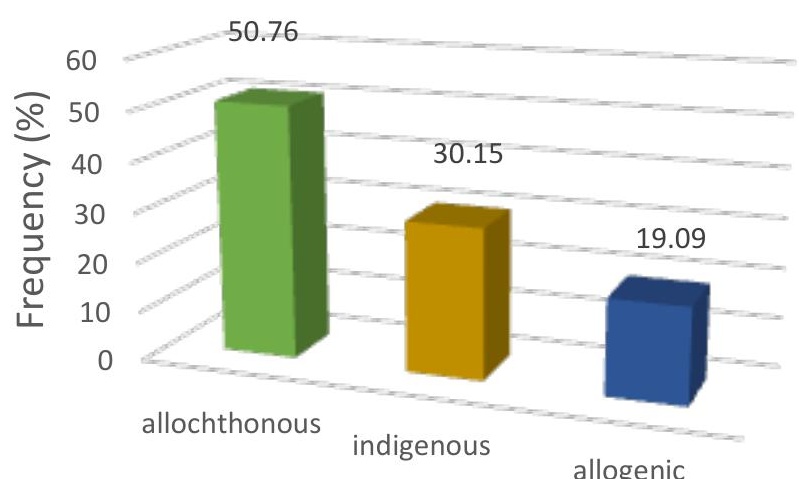


Figure 4:- Frequency of the origins of the respondents

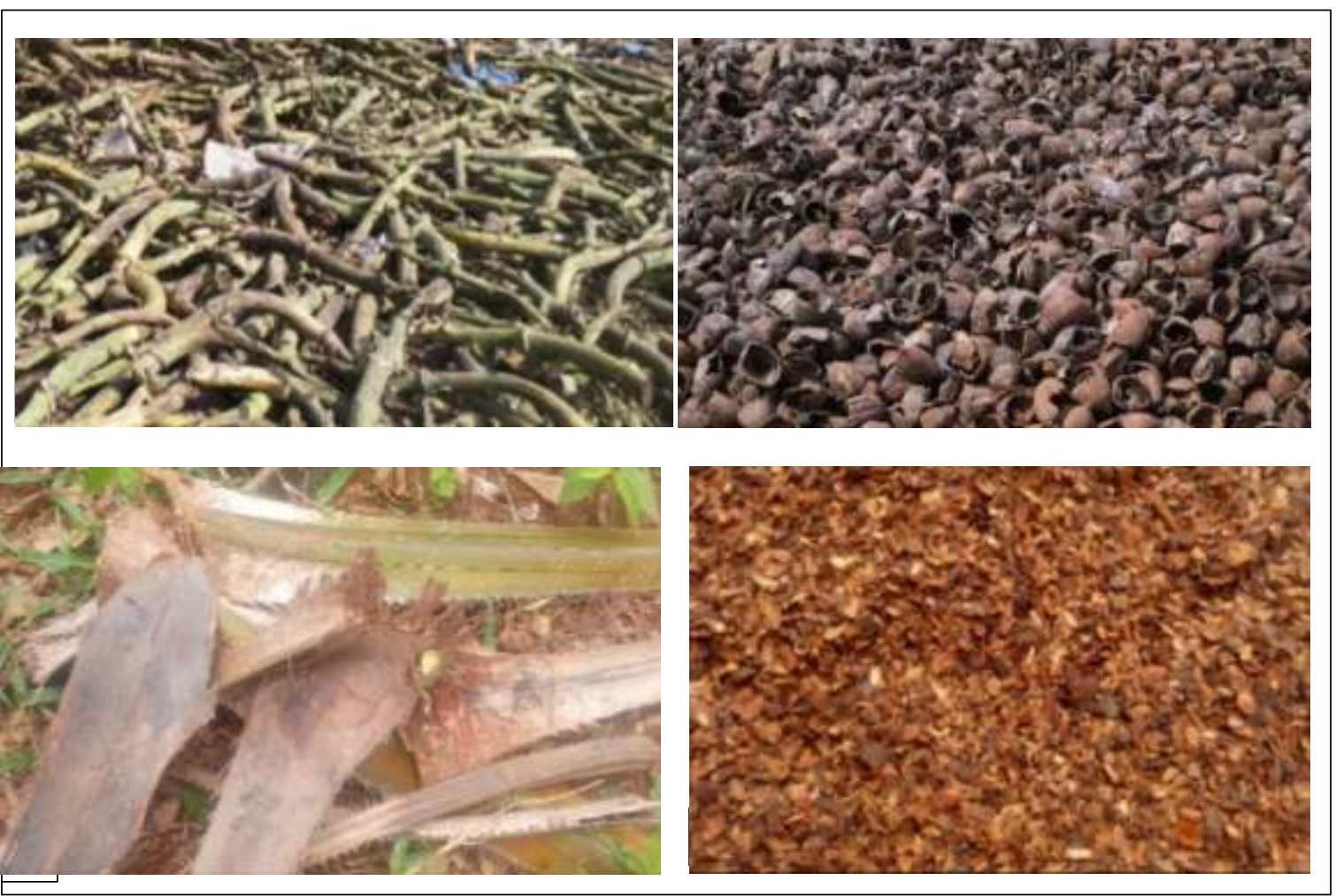

Figure 5:- The most commonly used coproducts for artisanal potash production (a): banana stubble; (b) cocoa pods; (c): branches of the palm tree; (d): parches of coffee

\section{- Description of the methods of production of artisanal potash}

The plot of potash production from banana stalks, cocoa pods or coffee parches is shown in figure 6 . The materials are burned after drying to obtain ash. This is used to make the potash liquid. Indeed, the ash put in a filtering device (a barrel slotted horizontally or a perforated pear from the bottom) placed on pieces of wood placed on another container placed lower, is gradually soaked with water. This water which passes through the ash is filtered and 
collected lower in a container arranged for this purpose. It is thus rich in potash (liquid potash). This process can continue in an interval of one to five days. The liquid is transferred into a large pear or barrel cut and prepared for one, two or even three days depending on the amount of liquid potash prepared and the quality of the fire until solid potash (Fig. 7).

Potash in this method is obtained from the branches of the palm tree. Dried, they are burned in order to obtain ash, then this ash is recovered potash liquid through the same filtering device described above. The liquid is transferred to a large pear or barrel cut and put on fire (preparation). This preparation step is not intended to solidify the "liquid potash" but to produce a supernatant. Indeed, once the liquid on fire, the person preparing must pay special attention. Thus, as soon as it appears a supernatant, this one with the help of a ladle is delicately recover and pour into fireplace fire ash disposed in a clean place with a hollow made inside. The liquid is gradually poured until the formation of a more or less solid ball of potash. This is gently removed and put in the sun to solidify (Fig. 8).

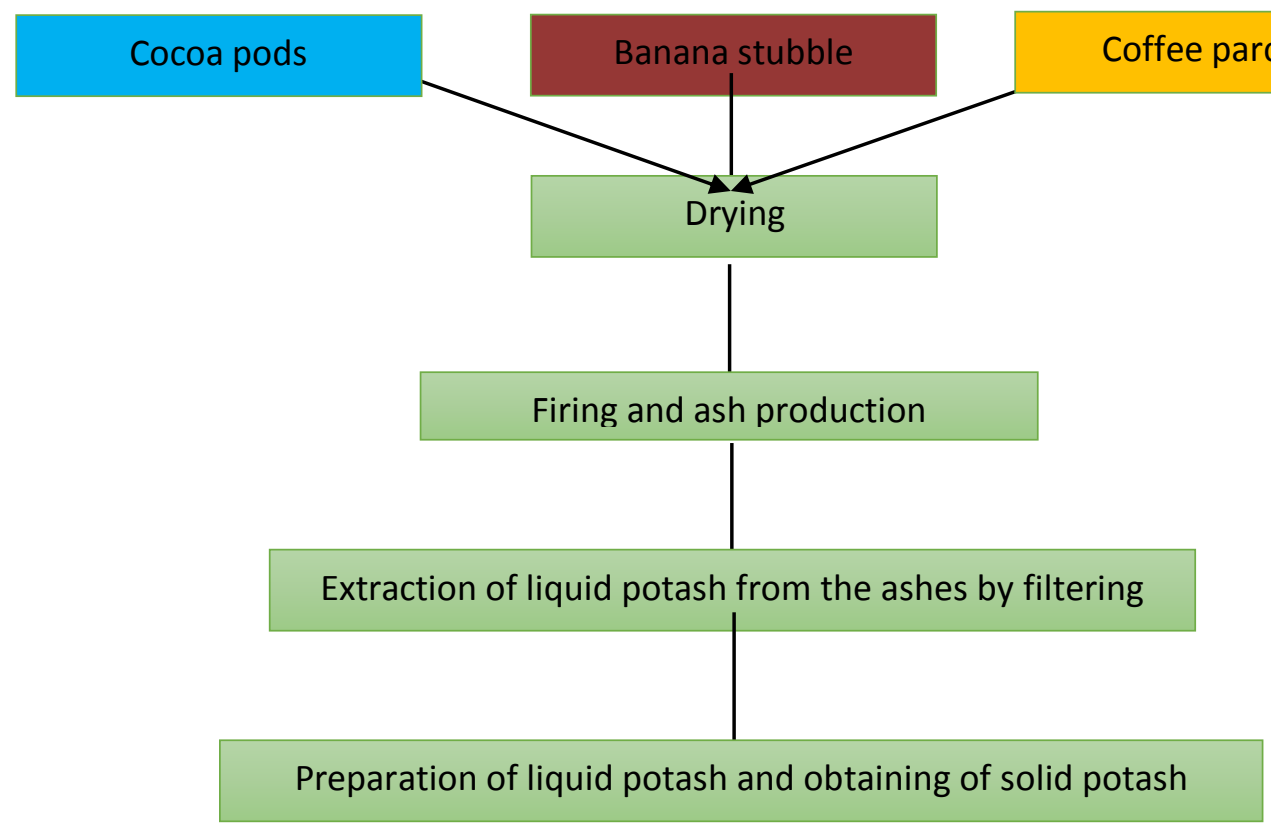

Figure 6:- Method of producing potash made from cocoa pods, banana stubble and coffee parches

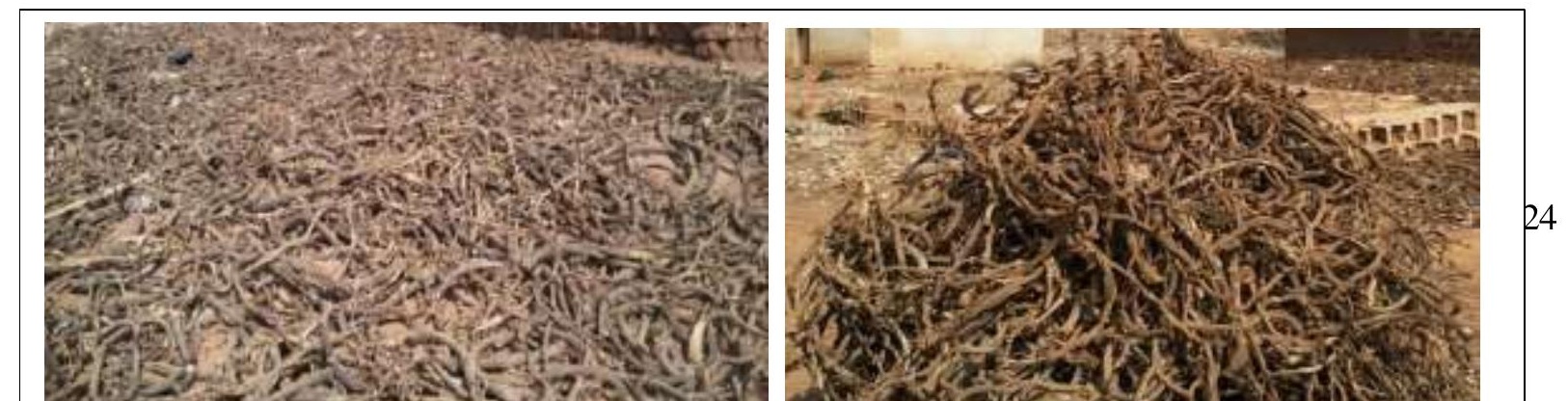




\section{A}

Figure 7:- Example of a potash production process: case of banana stubble, (A): Banana thatch drying; (B): Banana stalks piled up for burning; (C): ash collected after firing; (D): a filtering device; (E): Preparation of the liquid potash obtained after filtering; (F): solid potash obtained at the end of the preparation.

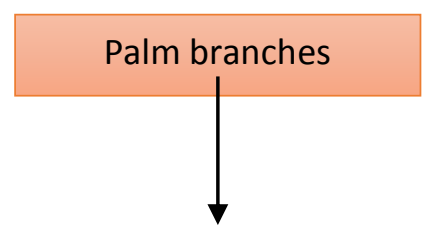




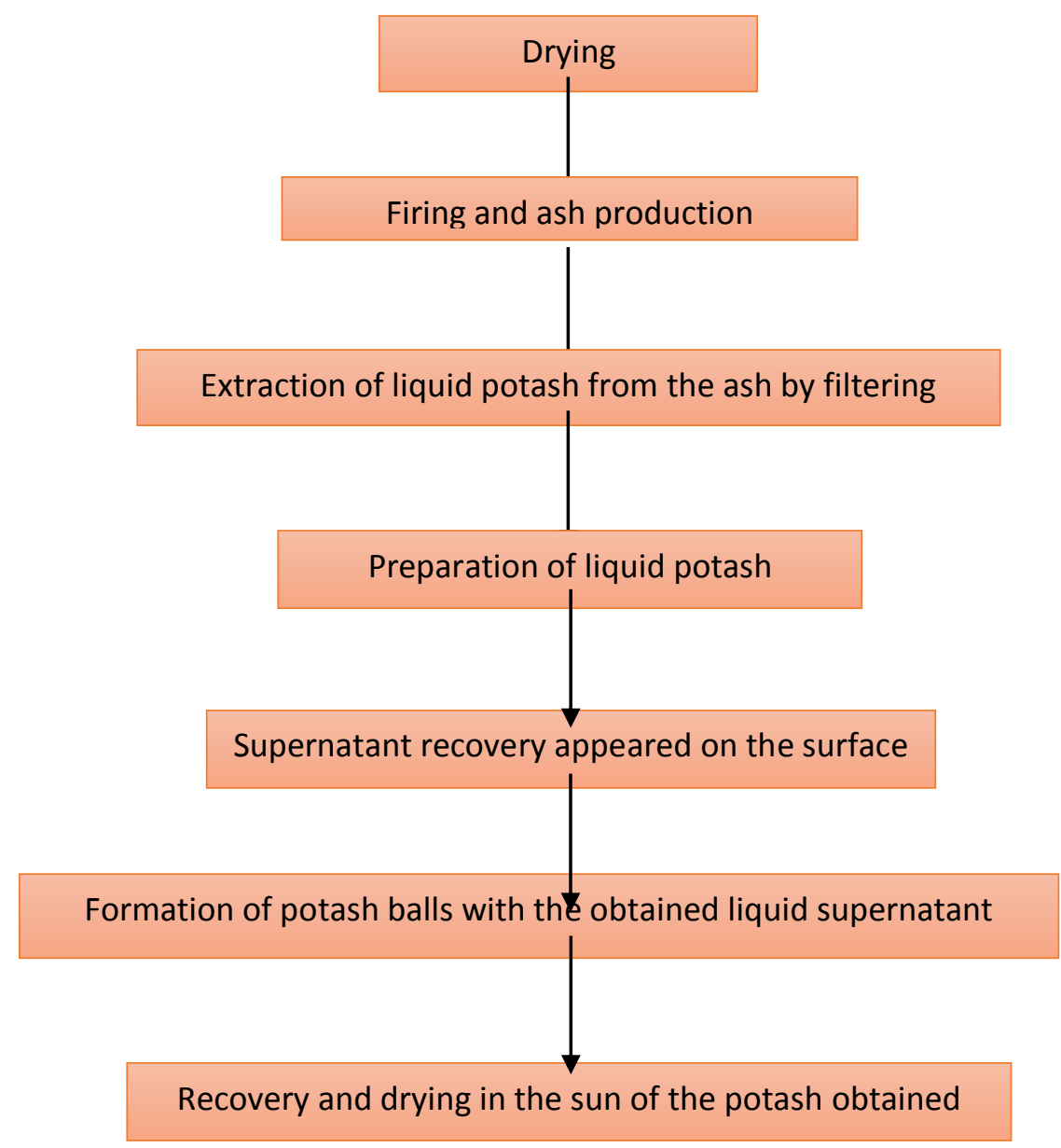

Figure 8:- Method of production of potash based on palm branches

\section{Potash and uses:-}

\section{- Potash potash as a food additive}

Potash potash is used in cooking as an ingredient of certain sauces (okra, klala, tomato) and on certain foods (maize, beans, hard meat). It is used in liquid form by $9.76 \%$ of consumers surveyed while $90.24 \%$ of consumers surveyed use it in solid form (Fig. 9). However potash in liquid form is that produced by a third person and intended for his personal consumption. Potash produced for commercial purposes, is a solid product. Of the consumers surveyed, $22 \%$ said they used it only as an ingredient in sauces, $26.03 \%$ used it as an ingredient in food, and $51.41 \%$ said it was used in foods as well as in food. in sauces (Fig. 10).

They use it to keep sauces longer, to make sticky sauces like okra and " kplala ", eliminate the sour taste of foods like tomatoes, facilitate cooking (meat, beef skin and beans) or again to recover a sauce in fermentation. 


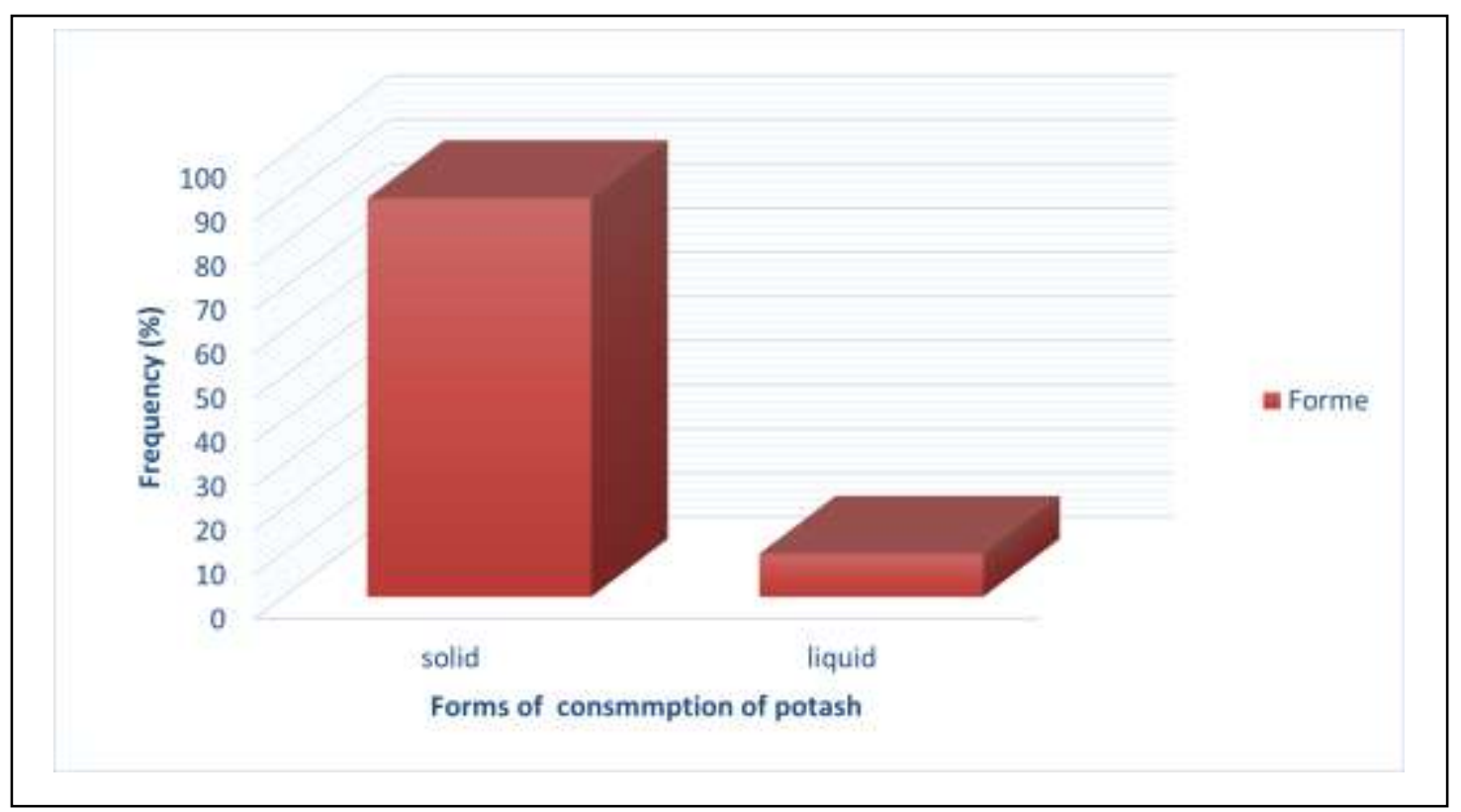

Figure 9:- Frequency of forms of potash consumption

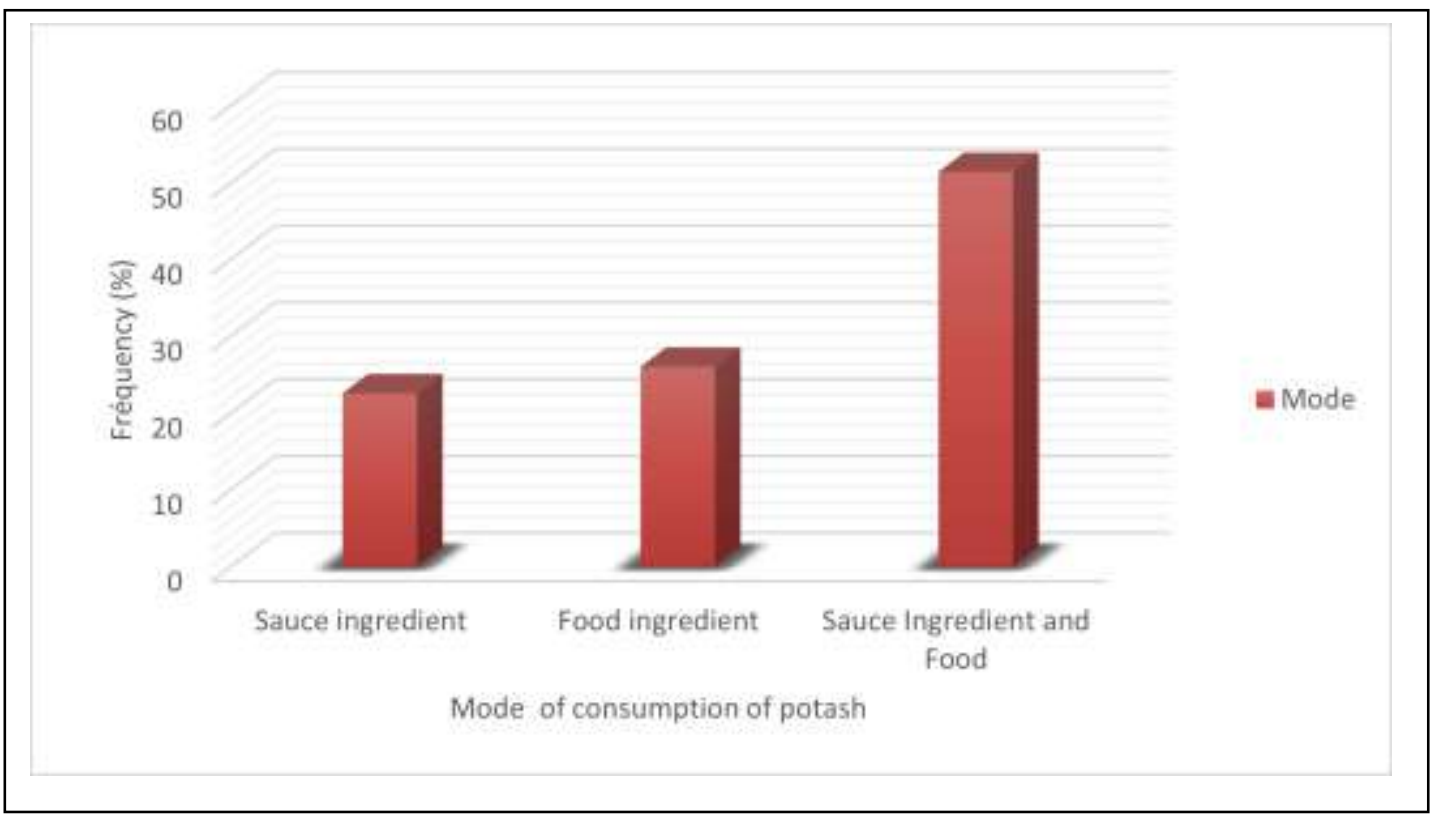

Figure 10:- Frequency of potash consumption patterns

\section{- Artisan potash as a medicine}

Of the 461 respondents, 259 or $56.18 \%$ said they know and use potash as a traditional medicine. Thus, $81.46 \%$ of the latter said they know potash as a medicine of the scab. $42 \%$ know it as treatment against ringworm, $19.69 \%$ for constipation, $29.34 \%$ for stomach pain, $2.31 \%$ for wounds, $66.79 \%$ for cough in addition to other medications and 78.37\% recognized potash as a supplement to many drugs in several diseases treated by traditional medicine (Fig. 11). 
In addition, potash potash, especially that based on palm, is considered a powerful remedy by traditional medicine (Akan especially) who uses it very frequently as a supplement to other drugs in many cases of more serious diseases.

\section{- Other uses}

In addition to its use as food and as a traditional medicine, potash potash is also used for the manufacture of traditional soaps.

\section{Conservation material}

Potash conservation equipment, from producers to consumers and traders, consists mostly of plastic packaging in $62.91 \%$ of the cases, followed by a rubber box in $22.77 \%$ of cases, empty bottle $(13.23 \%)$ and rice sack (polypropylene sack) in $1.08 \%$ of cases (Fig. 12). The choice of these materials for the conservation of potash is related to the concern to preserve this food against the humidity of the air and the water which causes its melting on contact. In addition, well-preserved potash would keep its nutritional quality for many years according to almost all respondents.

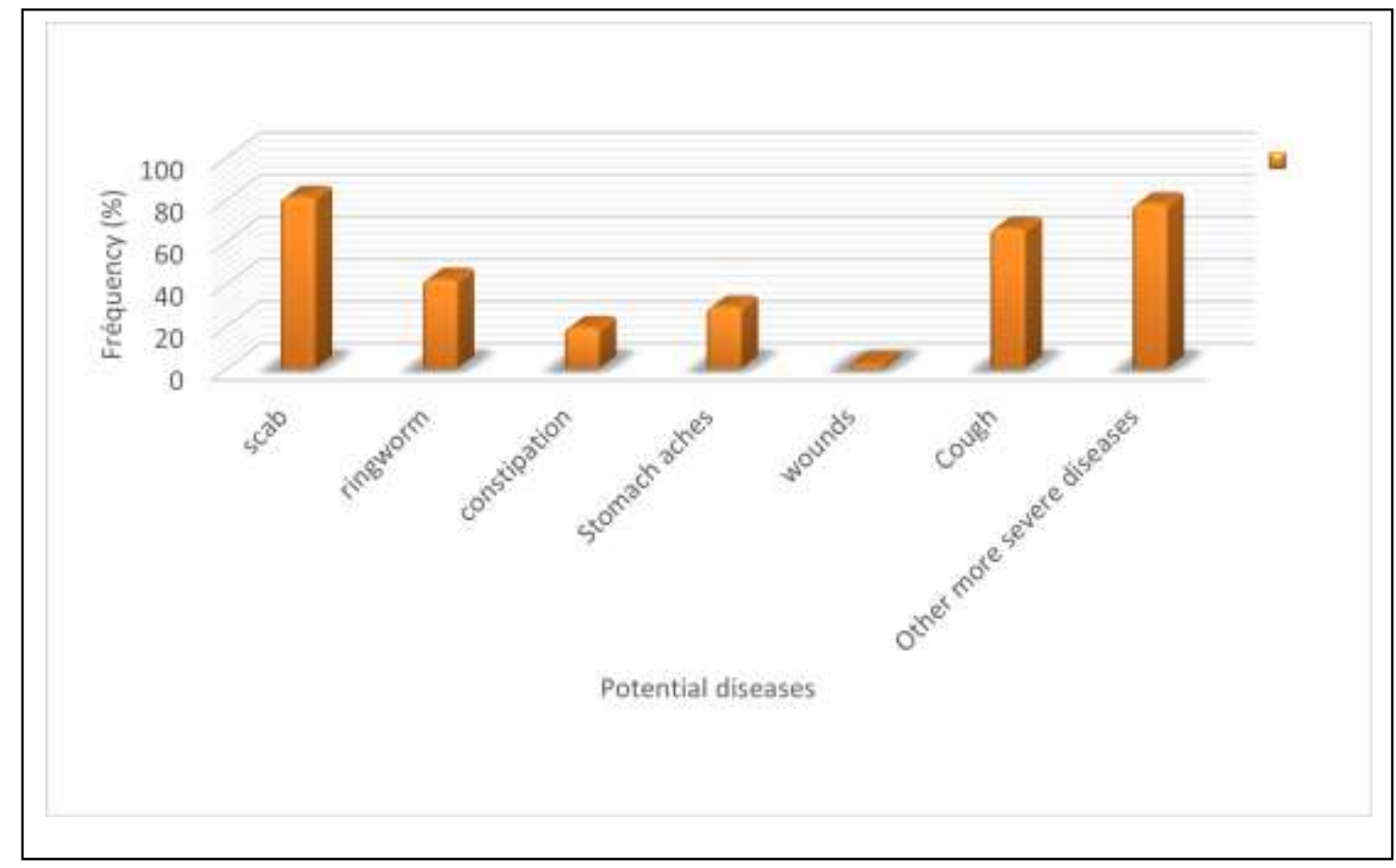

Figure 11:- Frequency of use of potash potash as medicine in some cases of diseases 


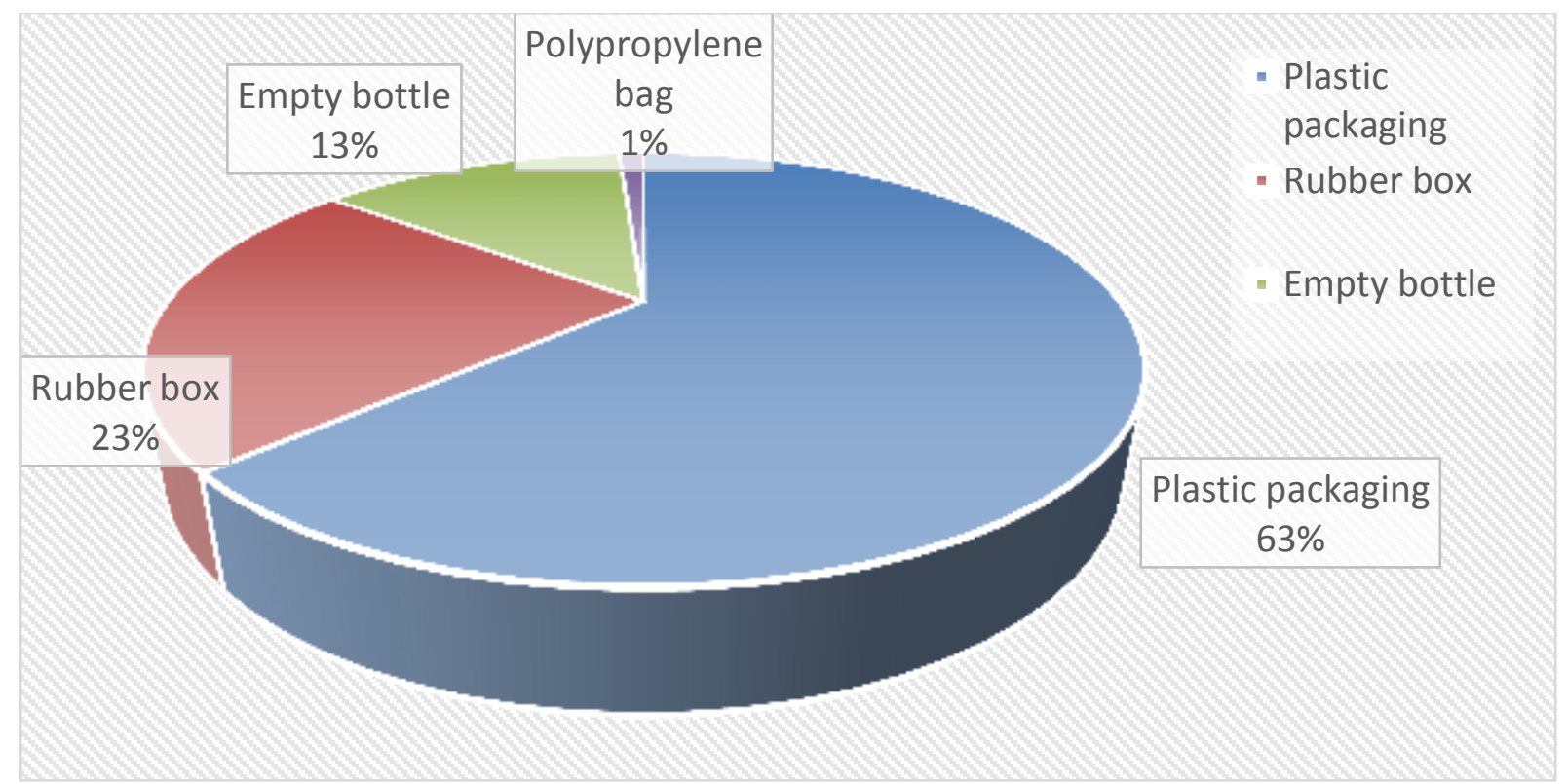

Figure 12:- Frequency of conservation materials used by respondents

\section{Discussion:-}

The study carried out among the actors of the potash sector, showed that several agricultural co-products are used to produce the potash whose most used in the Haut Sassandra are, the co-products resulting from: cocoa pods, parches of coffee, branches of the palm tree and banana stubble. This could be related to the fact that they come from products available in the region. In fact, the Haut-Sassandra region is the second largest cocoa zone and the country's leading coffee producer (Koffie-Bikpo, 2013). The region presents itself as the second pioneer frontier for food crop production (Adou, 2012). At the same time, the physicochemical analysis of potash from co-products most commonly used for the production of potash, indicated a very high content of ash (minerals) $(81.68 \pm 0.27 \%$ for potash based on coffee at $93.70 \pm 1.36 \%$ for potash from palm branches). These results are similar to those of Biego et al. (2011), which obtained from the ashes of agricultural co-products, important sources of mineral elements. These authors showed that plantain, cocoa pod and parchment co-products contained $96.40 \%, 89.70 \%$ and $84.20 \%$ of ash (minerals), respectively. According to these researchers, agricultural co-products are an important source of potassium. Analyzes carried out by the latter on those derived from pineapple, cocoa, coffee, maize, palm, coconut, banana indicate a potassium content varying from $18 \pm 0.46 \%$ for co-products derived from coconut at 42.5 $\pm 0.04 \%$ (co-products of coffee).

The methods of production of the different potahes are all identical except that of potash made from palm branches which proves to be complex. This is because the preparation step requires continual monitoring to be able to sample the supernatant in time when it appears on the surface of the liquid. However, few people are able to produce this potash. This would explain the low use of these co-products by producers encountered during our investigation. Moreover, the observation is that the method of producing potash potash has not changed over time since Assogbadjo (2006) described the same process in the production of potash from the pericarp, the capsule, the bark of the potash. trunk, flowers and branches of African baobab (Adansonia digitata L.).

Very little literature is available on the study of potash. According to the results of the study on the use of the latter, it is noted that the potash would be used in human food but also in traditional medicine and to produce soap as shown the work of Assogbadjo (2006). In food, potash would be used as an additive as a preservative but also to reduce the acidity of certain foods thanks to its alkaline character revealed by the analysis results ( $\mathrm{pH}$ between 8.64 and 11.54). Alkaline foods should be $70 \%$ of the menus because a diet too acidic is bad for the body. A state of latent metabolic acidosis (AML) has thus been associated with an acid diet (Cordain et al, 2005). This phenomenon of AML will solicit at the level of the body a number of compensatory mechanisms (homeostatic) (Remer, 2001): mobilization of bone minerals (mainly calcium) and amino acids of muscle proteins. However, such situations can be avoided if the diet is balanced, providing alkalizing compounds itself (Demigne, 2008). Potash would be a hygroscopic product which would require the use of packaging material suitable for its conservation. This material should be able to prevent it from coming into contact with air humidity and water. The use of plastic packaging (at 
$62.91 \%$ ), rubber box (at 22.77\%), empty bottle (at 13.23\%) and rice bag (polypropylene bag) (at 1, 08\%) is the reason.

\section{Conclusion:-}

The results show us that potash is produced with a multitude of agricultural co-products. Of these, banana stubble, coffee parchment, palm branches and cocoa pods are the most used in the Haut Sassandra region to produce potash. However, for this production, apart from that of palm-based potash, which differs somewhat, the same method is used for all the others. The packaging used for preservation is mainly composed of plastic packaging in $62.91 \%$ of cases but also of rubber box (22.77\%), empty bottle (13.23\%) and rice bag (polypropylene) (1.08\%). These are used to preserve this hygroscopic product against moisture.

\section{Références bibliographiques:-}

1. Adou D. L. (2012). L'économie de plantation et la dynamique de peuplement dans la région du HautSassandra, Thèse unique de doctorat en géographie, Université Félix Houphouët-Boigny, Abidjan-Cocody, 286 p.

2. Anonyme 1 (2014). Recensement Général de la Population et de l'Habitat. Rapport d'exécution

et présentation des principaux résultats. Institut National de la Statistique, $49 \mathrm{p}$.

3. Anonyme 2 (2013). Culture annuelle. CNRA, 46p.

4. Assogbadjo A. E. (2006). Importance socio-économique et étude de la variabilité écologique, morphologique, génétique et biochimique du baobab (Adansonia digitata L.) au Bénin. Thèse de doctorat. Faculty of Bioscience Engineering, Ghent University, Belgium, 213p.

5. BAFD/OCDE (2006). Perspectives Economiques en Afrique: Côte d'Ivoire, Banque Africaine de Développement et Organisation pour la Coopération et le Développement Economique, 53p.

6. Biego G.H.M., Koffi K.M., Chatigre K.O., N'doume C. et Kouadio L.P. (2011). Détermination des minéraux de sous-produits de cultures, International Journal of pharma and bio sciences, 12 (2) : 13-24.

7. BM (2013). Douanes françaises et ivoiriennes citées par Business France 2013 et 2014 IGN, MAAF, Ambassade de France au Sénégal, 10p.

8. Boucherba N. (2015). Valorisation des résidus agro-industriels. Mémoire en Sciences de la Nature et de la Vie Département de Microbiologie, Université Abderrahmane Mira de Béjaïa, Algérie, 73 p.

9. Cordain L., Eaton S.B., Sebastian A., Mann N., Lindeberg S., Watkins B.A., O’Keefe J.H. Brand-Miller J. (2005). Origins and evolution of the Western diet: health implications for the $21 \mathrm{st}$ century. American Journal of Clinical Nutrition, 81: 341-354.

10. Demigné C. (2008). Fonctionnalité alcalinisante, In “Aliments Fonctionnels”, Roberfroid M., Coxam V., Delzenne N., Editions Tec \& Doc, Cachan, pp 541-562.

11. Freiwalds J. (1974). Find new uses for coffee and tea by-products in cattle food or as fuel substitutes. Tea and Coffee Trade Journal, $1: 29$ - 37.

12. Grigoraş C. G. (2012). Valorisation des fruits et des sous-produits de l'industrie de transformation des fruits par extraction des composés bioactifs. Thèse de Doctorat en cotutelle internationale de l'université d'Orléans et de l'Université « Vasile Alecsandri» de Bacău, Orléans, 261 p.

13. Koffie-Bikpo C. Y. (2013). La région du Haut-Sassandra dans la distribution des produits vivriers agricoles. Revue de Géographie Tropicale et d'Environnement, 2 : 95-103.

14. Mara (1992). Bulletin trimestriel de statistiques agricoles de la Direction Générale de l'Agriculture. $\mathrm{N}^{\circ} 23 / 04 / 1992$, Direction de la programmation, Ministère de l'Agriculture et des ressources Animales, Abidjan, Côte d'Ivoire.

15. Remer T. (2001). Influence of nutrition on acid-base balance-metabolic aspects. European Journal of Nutrition, 40: 214-220.

16. Sangaré A., Koffi E., Akamou F. et Fall C. A. (2009). État des ressources phylogénétiques pour l'alimentation et l'agriculture: Second rapport national. Rapport national sur l'état des ressources phylogénétiques pour l'alimentation et l'agriculture. $65 \mathrm{p}$. 